\title{
Farming data: testing climatic and palaeoenvironmental effect on Neolithic Adriatic stockbreeding and hunting through zooarchaeological meta-analysis
}

\author{
J. S. Gaastra (j.gaastra@ucl.ac.uk) and M. Vander Linden \\ Institute of Archaeology, University College London, United Kingdom
}

\section{Introduction}

The introduction of plant and animal domesticates across Europe during the Early and Middle Holocene is characterised by extensive variation, observed for instance in local rates of advance (Bocquet-Appel et al. 2009), and material assemblages (e.g. Whittle 1996). Likewise, regional and pan-European reviews of both archaeobotanical and zooarchaeological data have revealed extensive spatial and temporal differences in the distribution of the domesticated species during the spread of farming. Yet, it remains unclear to what extent this variation reflects inherited cultural choices and traditions (e.g. Colledge et al., 2005), or early farmers' adaptive capacities to new environments, (e.g. Conolly et al., 2012) as new species are introduced in regions whose ecologies can significantly differ from those of their wild progenitors, sometimes with hugely detrimental implications for the local vegetation (e.g. Pilaar Birch and Leppard, 2016). Most recently, Manning and colleagues (2013) suggested, on basis of a multi-linear regression analysis done on a pan-European zooarchaeological dataset, that environmental variables account for $23-30 \%$ of the variance for domesticates, and culture for a further $10-13 \%$ (although the accuracy of these results is hampered by non-considering possible bias retrieval: Orton et al. 2016).

This contribution aims at unravelling the respective weight of some of these factors (environment, climate, culture) by investigating patterns of stockbreeding and hunting across the Adriatic basin through a meta-analysis of the zooarchaeological record for the first two millennia following the local introduction of domestic animals. This research area provides an ideal case-study through which to explore these questions for several reasons. Firstly, the quality of the existing archaeological information allows a relatively fine-grained analysis, based upon an extensive, well-dated dataset. Secondly, available palaeoenvironmental data and reconstructions offer a robust baseline for testing possible correlations between ecological, climatic and zooarchaeological variations.

Current theories regarding the status of zooarchaeological assemblages associated with the spread of early farming across the Adriatic consider, on the one hand, the existence of a consistent 'package' of exploitation practices or, on the other hand, adaptations to local environments by initial settlers, followed by further consolidation of husbandry regimes through time, including different functional use of cave sites, especially in upland areas (Frame, 2008; Lelli et al., 2012; Malone, 2003; McClure and Podrug, 2016; Robb, 2014; Robb and Van Hove, 2003; Tagliacozzo, 2005). Whilst somewhat simplistic, this opposition is helpful in order to shape two main alternative hypotheses to be tested here: either that the spread of the Neolithic is associated with a relatively homogenous set of practices, in accordance with the speed of this process and the relative similarity of environments so that each phase of expansion reproduces (to some extent) the animal exploitation practices 
found in its area of origins; or that Neolithic husbandry and hunting regimes are correlated with regional environmental and climatic factors, water availability being a key element. For instance, increased aridity in some environments or chronological periods would imply a move away from cattle and pigs, with their higher water requirements, towards a greater focus on sheep and goats.

\section{Archaeological and environmental background}

\section{Chronology and landscape Use}

Plant and animal domesticates are introduced in the Adriatic Sea around $8000 \mathrm{cal}$. BP (Forenbaher et al., 2013). Two major episodes of diffusion can be inferred from the radiocarbon record. During the first phase, dated between c.8000 and $7500 \mathrm{cal}$. BP, Neolithic sites are found along the entire eastern Adriatic coast, from Albania to southernmost tip of the Istrian peninsula, and mostly occupy coastal and island locations. By contrast, early Neolithic sites on the Adriatic western coast are contained within southern Italy (Figure 1), with concentrations along the Tavoliere plain and the Otranto valley (Whitehouse, 2013). This region provided a large coastal plain, and, in some areas, also afforded rich coastal lagoons along which settlements were founded (Caldara et al., 2002, Di Rita et al., 2011). Largely because of the different histories of research, this period is known mainly from cave sites on the eastern Adriatic coast (Forenbaher et al., 2013; but see Moore et al., 2007b) and mainly from open-air settlements on the western Adriatic (Whitehouse, 2013). In all cases, settlements are associated with a relatively uniform archaeological complex characterised by the Impresso pottery style.

A second phase of diffusion of early farming practices starts around 7500 cal. BP, with an expansion of settlements up to the headwaters of the Adriatic along both coasts, to the Trieste Karst on the eastern Adriatic and through central Italy and onto the Po plain on the western Adriatic (Figure 1). Coastal sites still dominate, but with an increasing presence further inland along river valleys, and into upland landscapes (Malone, 2003; Whitehouse, 2013). It is also noticeable that, until the end of the $8^{\text {th }}$ millennium cal. BP, there is a sizeable presence of late Mesolithic foragers across the entire peri-Alpine area (Franco, 2011). The corresponding sites are not considered here, as our focus lies upon the variability and impact of farming practices across the Adriatic catchment.

The following $7^{\text {th }}$ millennium cal. BP sees further infilling, with settlements continuing up river valleys away from the coasts and further exploitation of upland environments (Figure 1), including the sub-alpine zones of the Italian Alps, as well as the Julian and Dinaric Alps for the eastern Adriatic (Forenbaher et al., 2013, Vander Linden et al., 2014). In cultural terms, the relative homogeneity of the Impresso complex gives way to increased fragmentation, characterised by the development of local, small-scale archaeological cultures generally defined upon ceramic styles (Malone, 2003; McClure et al., 2014; Robb, 2014, Forenbaher et al., 2013).

\section{Environmentalbackground}

Following the terminology of Walker et al. (2012), the sequence investigated here lies covers the first half of the middle Holocene. The present-day Adriatic basin presents an 
overall bi-partition in terms of vegetation zones with, along the eastern and south-eastern shores, thermo-, meso- and supra-Mediterranean zones, the rest of the area lying outside the Mediterranean zone per se and being characterised as sub-Mediterranean. This division, reflecting a general north-south gradient in precipitation across the Mediterranean, is generally considered as an acceptable template for the middle Holocene (Roberts et al., 2011). Palaeoenvironmental data allow to obtain further precision regarding spatial and temporal changes. It must be noticed, however, that the available record is relatively uneven. On the eastern coast, data are restricted to a few scattered lake cores (Jahns and van den Bogaard, 1998; Mazzini et al., 2016; Sadori et al., 2011; Wunsama et al., 1999). On the western coast, the record is arguably better, with a combination of lake and offshore cores (e.g. Magny et al., 2012a, 2012b; Combourieu et al., 2013).

Between $9000 \mathrm{cal}$. BP and $7000 \mathrm{cal}$. BP, average temperatures were probably higher than modern values, as was precipitation (Giraudi et al., 2011). Regional differences are noticeable, in particular in terms of seasonality as the northern Adriatic experienced cooler summers (Peyron et al., 2011). From c.7000 cal. BP onwards, climatic reconstructions suggest a gradual decline in precipitation (e.g. Combourieu et al., 2013, Sadori et al., 2011), with marked spatial and temporal variation. In Apulia for instance, Fiorentino et al (2013) identify an arid period lasting between 7000 and $6600 \mathrm{cal}$. BP. This dry phase is followed by a cool and wet episode peaking at $6400 \mathrm{cal}$. BP, as suggested by marine pollen core MD-90917 (Combourieu et al., 2013). It is also noticeable that the regional pattern of seasonal divergence previously noted still applies, the overall period between 9500-6500 cal. BP coinciding with "a maximum of winter and summer precipitation in south-central Mediterranean and of winter precipitation in north-central Italy" (Magny et al., 2012: 295). Overall, landscapes across the entire research area would thus have been characterised by patchiness (Roberts et al., 2011).

There are numerous potential signatures for human impact, generally involving changes in the ratios of arboreal vs non-arboreal pollen and changes in erosion patterns - all pointing towards the opening of landscapes related to deforestation by early farming communities. Whilst sporadically reported in multiple areas, such signatures of anthropogenic landscape change are limited for the beginning of the middle Holocene, especially when compared to more obvious later Bronze Age signals (Allen et al., 2002, Branch and Marini, 2014;

Guilizzoni et al., 2002; McClure, 2013; Mercuri, 2014; Piccarreta, et al 2011; Simonneau et al., 2013).

\begin{tabular}{|c|c|c|c|c|c|c|c|}
\hline Phase & years cal BP & Dalmatia & Karst & South Italy & Central Italy & Po Plain & Sub-Alpine \\
\hline 1 & $\begin{array}{l}\text { c.81/8000 to } \\
75 / 7400 \text { cal BP }\end{array}$ & Impresso & & Impresso & & & \\
\hline 2 & $\begin{array}{l}\text { c.75/7400 to } \\
7000 \text { cal BP }\end{array}$ & Danilo & $\begin{array}{l}\text { Danilo } \\
\text {-Vlaška }\end{array}$ & $\begin{array}{c}\text { Impresso } \\
\text { Stentinello }\end{array}$ & $\begin{array}{c}\text { Impresso } \\
\text { Sasso-Fiorano }\end{array}$ & Fagnigola, Vhò & \\
\hline 3 & $\begin{array}{l}\text { c.7000 to } \\
6500 \text { cal BP }\end{array}$ & Hvar & $\begin{array}{l}\text { Danilo } \\
\text {-Vlaška }\end{array}$ & $\begin{array}{l}\text { Serro d'Alto } \\
\text { Ripoli }\end{array}$ & Sasso-Fiorano & $\begin{array}{c}\text { Fiorano, Vhò } \\
\text { Fagnigola, VBQ }\end{array}$ & $\begin{array}{c}\text { Gaban } \\
\text { VBQ }\end{array}$ \\
\hline 4 & $\begin{array}{l}\text { c.6500 to } \\
6000 \text { cal BP }\end{array}$ & $\begin{array}{l}\text { Late } \\
\text { Hvar }\end{array}$ & $\begin{array}{l}\text { Danilo- } \\
\text {-Vlaška }\end{array}$ & $\begin{array}{l}\text { Scaloria } \\
\text { Diana }\end{array}$ & $\begin{array}{l}\text { Ripoli } \\
\text { Diana }\end{array}$ & VBQ & VBQ \\
\hline
\end{tabular}

Table 1: Chronological ranges of phases used in this study, and the cultural groups present in the studied regions. Cultural groups have been assigned to regions and phases following Forenbaher et al. (2013), Malone (2003), Skeates (2013) and Whitehouse (2013). 


\section{Methods and materials}

The present study is based upon a database of published zooarchaeological taxonomic data for Neolithic sites in the Adriatic catchment area, supplemented by several unpublished assemblages either directly studied by the first author, or kindly supplied by colleagues. The temporal brackets of our data collection lie between $8000 \mathrm{cal}$. BP, corres ponding to the earliest local occurrence of animal domesticates, and 6000 cal. BP. Although the latter date is somewhat arbitrary, it offers a large enough window of time for analysis. Given the multiplicity of local relative chronologies, the dataset has been divided into four 500 -year chronological phases for comparative purposes (Table 1). This four-fold division reproduces the overall development of the Neolithic settlement pattern across this area, with the first 500 years corresponding the initial spread of early farming along the eastern and southwestern coast, the second phase seeing the generalisation of farming across the entire Adriatic catchment, and the last thousand years witnessing the gradual diversification of landscapes used. These phases also roughly correspond to broad regional climatic oscillations as discussed above.

In total, the dataset includes 85,955 specimens from 111 archaeological phases spread over 93 sites. Areas sampled range from individual test trenches to large open-area excavations, encompassing both caves and open- air sites (both with and without ditches). Sites, chronological phasing of samples, and sources are detailed in Table 2 with their locations shown in Figure 1.

[Figure 1]

\begin{tabular}{|c|c|c|c|c|c|}
\hline $\mathrm{n}$ & Site & Period & Type & NISP & Source \\
\hline \multicolumn{6}{|c|}{ Dalmatian Coast } \\
\hline 1 & Crno Vrlo & 1 & open & 3523 & Radović 2011 \\
\hline 2 & Danilo-Bitinj & 2 & open & 1717 & Moore et al. 2007a Legge \& Moore 2011 \\
\hline 3 & Grapčeva špilja & 4 & cave & 1637 & Frame 2008 \\
\hline 4 & Kargadur & 1 & open & 674 & Radović 2011 \\
\hline 5 & Nin & 1 & open & 394 & Schwartz 1988 \\
\hline \multirow[t]{2}{*}{6} & Pupićina peć & 2 & cave & 2873 & Miracle \& Pugsley 2006 \\
\hline & & 3 & cave & 504 & Miracle \& Pugsley 2006 \\
\hline 7 & $\mathrm{~S}_{\text {pila }}$ & 1 & cave & 1055 & Marković 1985 \\
\hline \multirow[t]{4}{*}{8} & Spila Nakovana & 1 & cave & 310 & Gaastra, unpublished \\
\hline & & 2 & cave & 583 & Gaastra, unpublished \\
\hline & & 3 & cave & 272 & Gaastra, unpublished \\
\hline & & 4 & cave & 250 & Gaastra, unpublished \\
\hline 9 & Tinj-Podlivade & 1 & open & 3209 & Chapman et al. 1996 \\
\hline \multirow[t]{2}{*}{10} & Vela peć & 2 & cave & 347 & Radović 2011 \\
\hline & & 3 & cave & 220 & Radović 2011 \\
\hline \multirow[t]{4}{*}{11} & Vela spila (Korčula) & 1 & cave & 206 & Radović 2011 \\
\hline & & 2 & cave & 346 & Radović 2011 \\
\hline & & 3 & cave & 264 & Gaastra, unpublished \\
\hline & & 4 & cave & 154 & Gaastra, unpublished \\
\hline 12 & Vela špilja / jama (Lošinj) & 1 & cave & 368 & Pilaar Birch 2017 \\
\hline 13 & Zemunica & 1 & cave & 283 & Radović 2011 \\
\hline \multicolumn{6}{|c|}{ Trieste Karst } \\
\hline 14 & Cladrecis & 2 & cave & 1054 & Riedel 1984a \\
\hline 15 & Grotta Azzura & 2 & cave & 255 & Cremonesi et al. 1984 \\
\hline 16 & Grotta degli Zingari & 2 & cave & 227 & Bon 1996 \\
\hline 17 & Grotta della Edera & 2 & cave & 211 & Boschin \& Riedel 2000 \\
\hline
\end{tabular}




\begin{tabular}{|c|c|c|c|c|c|}
\hline & & 3 & cave & 1099 & Boschin \& Riedel 2000 \\
\hline & & 4 & cave & 501 & Boschin \& Riedel 2000 \\
\hline 18 & Mala Triglavca 8 & 3 & cave & 186 & Turk 1980 \\
\hline 19 & Grotta Mitreo & 3 & cave & 163 & Petrucci 1997 \\
\hline \multicolumn{6}{|c|}{ Southern Italy } \\
\hline 20 & Baselice & 3 & open & 477 & Curci et al. 2012; Langella et al. 2003 \\
\hline 21 & Cala Colombo & 4 & cave & 941 & Giove et al 1977 \\
\hline 22 & Capo Alfiere & 3 & open & 2140 & Gal 2010; Scali 1990 \\
\hline 23 & Favella & 1 & open & 250 & Tagliacozzo 2005 \\
\hline 24 & Grotta della Scaloria & 2 & cave & 1991 & Bökönyi 1985 \\
\hline 25 & Grotta della Tartaruga & 4 & cave & 268 & Wilkens, unpublished \\
\hline 26 & Lagnano da Piede & 1 & open & 178 & Mallory 1984-1987 \\
\hline 27 & Latronica, Grotta 3 & 2 & cave & 1633 & Wilkens PhD \\
\hline 28 & Masseria Candelaro & 2 & open & 107 & Bökn̈yi 1983 \\
\hline 29 & Masseria Valente & 1 & open & 242 & Bökönyi 1983 \\
\hline 30 & Mofletta & 1 & open & 303 & Wilkens 2002 \\
\hline 31 & Monte Maulo & 2 & open & 124 & Barker \& Clarke 1995 \\
\hline 32 & Passo di Corvo & 2 & open & 3040 & Sorrentino 1983 \\
\hline 33 & Rendina & 1 & open & 4548 & Bökönyi 1977-82 \\
\hline 34 & Rendina 3 & 1 & open & 331 & Wilkens 1996 \\
\hline 35 & Ripa Tetta & 1 & open & 146 & Wilkens 2002, 1988a \\
\hline \multirow[t]{2}{*}{36} & Santa Maria dAgnano & 2 & cave & 240 & Wilkens, unpublished \\
\hline & & 4 & cave & 243 & Wilkens, unpublished \\
\hline 37 & Santa Tecchia & 2 & open & 406 & Bökönyi 1983 \\
\hline \multirow[t]{2}{*}{38} & Scamuso & 1 & open & 388 & Wilkens 2002 \\
\hline & & 3 & open & 110 & Wilkens 2002 \\
\hline 39 & Serra Cicora & 4 & open & 208 & De Grossi Mazzorin \& Potenza 2014 \\
\hline 40 & Tirlecchia & 2 & open & 506 & Sorrentino 1984 \\
\hline 41 & Torre Sabea & 1 & open & 802 & Vigne 2003 \\
\hline \multirow[t]{3}{*}{42} & Trasano & 1 & cave & 3686 & Vigne \& Carrère (in Gillis 2012) \\
\hline & & 2 & cave & 1470 & Vigne \& Carrère (in Gillis 2012) \\
\hline & & 3 & cave & 1436 & Vigne \& Carrère (in Gillis 2012) \\
\hline 43 & Valle Cancelli & 4 & open & 186 & Tunzi et al 2011 \\
\hline \multicolumn{6}{|c|}{ Central Italy } \\
\hline 44 & Attiggio & 4 & open & 335 & Wilkens 1985 \\
\hline 45 & Berbentina di Sassoferrato & 4 & open & 422 & Wilkens 1989a \\
\hline 46 & Catignano & 3 & open & 1255 & Wilkens 2003 \\
\hline 47 & Citta Sant Angelo & 4 & open & 128 & De Pompeis 1978 \\
\hline 48 & Coppetella di Iesi & 4 & open & 543 & Wilkens 1988b \\
\hline 49 & Fontenoc di Recanati & 4 & open & 266 & Corridi 1998-2000 \\
\hline 50 & Fontenoc-Sam buch eto & 4 & open & 881 & Wilkens, unpublished \\
\hline 51 & Grotta Continenza & 2 & cave & 547 & Wilkens 1989 \\
\hline 52 & Grotta dei Piccioni & 2 & cave & 186 & Wilkens 1987a \\
\hline 53 & Grotta Sant'Angelo & 3 & cave & 168 & Albarella 1987/88 \\
\hline 54 & Maddalena di Muccia & 2 & open & 644 & Wilkens 1987a \\
\hline 55 & Monte Tinello & 3 & open & 564 & Wilkens 1989b \\
\hline 56 & Paterno & 3 & open & 119 & Wilkens, unpublished \\
\hline 57 & Piano Donatelli & 3 & open & 169 & Wilkens 1988c \\
\hline 58 & Porto d'Ascoli & 3 & open & 632 & Wilkens, unpublished \\
\hline 59 & Ripabianca di Monterado & 2 & open & 815 & Wilkens 1987a \\
\hline 60 & Ripoli & 4 & open & 1497 & Cremonesi 1965 \\
\hline 61 & San Marco, Gubbio & 2 & open & 505 & Clark 1992 \\
\hline 62 & Santa Maria in Selva & 4 & open & 2483 & Wilkens 1987b \\
\hline 63 & Santo Stefano di Ortucchio & 2 & open & 214 & Radi \& Wilkens 1989 \\
\hline 64 & Villaggio Leopardi & 2 & open & 154 & Wilkens 1987a \\
\hline \multicolumn{6}{|c|}{ Po Plain } \\
\hline 65 & Bannia - Palazzine di Sopra & 4 & open & 596 & Cottoni et al 1997; Petrucci 2005 \\
\hline 66 & Belforte & 4 & open & 729 & Catalani 1986 \\
\hline 67 & Botteghino & 4 & open & 218 & Berto et al. 2012 \\
\hline
\end{tabular}




\begin{tabular}{|c|c|c|c|c|c|}
\hline 68 & Casalecchio di Reno & 2 & open & 188 & Thun Hohenstein et al 2012 \\
\hline 69 & Casatico di Marcaria & 3 & open & 850 & Biagi et al. 1983 \\
\hline 70 & Cornuda & 4 & open & 817 & Riedel 1988 \\
\hline 71 & Fondo Tomollero & 3 & open & 320 & Jarman 1976 \\
\hline 72 & Gaione - Parco del Cinghio & 3 & open & 172 & De Grossi Mazzorin 2014 \\
\hline 73 & Isorella - Brescia & 3 & open & 176 & Bon et al. 2005 \\
\hline 74 & Maserà & 4 & open & 399 & Tecchiati 2015 \\
\hline 75 & Molino Cassarotto & 3 & open & 5696 & Jarman 1976 \\
\hline 76 & Monselice & 4 & open & 231 & Tecchiati 2015 \\
\hline 77 & Monte Tondo & 3 & open & 1078 & Jarman 1976 \\
\hline 78 & Ostiano & 3 & open & 281 & Biagi et al. 1983 \\
\hline 79 & Parma - Via Guidorossi & 3 & open & 393 & De Grossi Mazzorin 2014 \\
\hline 80 & Piancada & 2 & open & 319 & Petrucci et al. 2000 \\
\hline 81 & Razza & 3 & open & 158 & Cazzella et al. 1976 \\
\hline \multirow[t]{2}{*}{82} & Rivarolo Mantovano & 3 & open & 116 & Catalani 1984 \\
\hline & & 4 & open & 151 & Catalani 1984 \\
\hline 83 & Torri & 3 & open & 366 & Jarman 1976 \\
\hline 84 & Vho & 3 & open & 246 & Barker 1977 \\
\hline 85 & Vicofertile & 3 & open & 100 & De Grossi Mazzorin 2014 \\
\hline \multicolumn{6}{|c|}{ Sub-Alpine Italy } \\
\hline 86 & Bressanone - Stufles & 4 & open & 419 & Tecchiati \& Zanetti 2013 \\
\hline 87 & Fiave & 3 & open & 5441 & Jarman 1976 \\
\hline 88 & Isera & 4 & open & 273 & Jarman 1976 \\
\hline \multirow[t]{2}{*}{89} & La Vela & 3 & cave & 103 & Bazzanella 2002 \\
\hline & & 4 & cave & 216 & Bazzanella 2002 \\
\hline 90 & Moletta Patone & 3 & open & 173 & Riedel 1984b \\
\hline 91 & Monte Covolo & 3 & open & 893 & Barker 1977-1979 \\
\hline \multirow[t]{2}{*}{92} & Rocca de Rivoli & 3 & open & 2394 & Jarman 1976 \\
\hline & & 4 & open & 143 & Jarman 1976 \\
\hline 93 & Fingerhofes & 4 & open & 193 & Riedel 1986 \\
\hline
\end{tabular}

Table 2: Summary information for the sites and faunal assemblages used in this study.

91 out of 111 samples were assigned to one of four general phases on the basis of associated ${ }^{14} \mathrm{C}$ data. The remaining sites were assigned using the chronological ranges of their associated cultural group. As the duration of some of these groups spans more than one 500 -years phase, ${ }^{14} \mathrm{C}$ information has been given pre-eminence (i.e. the southern Italian Impresso has been split into phase 1 and phase 2 despite the fact that, in southern Italy, the Impresso culture is considered as a single period). While this approach thus sometimes divides sites belonging to the same cultural group, it also allows for the best chronological comparison of animal exploitation strategies across the multiple regions under consideration. Multiple samples from a single site were entered separately by phase. When multiple samples were present within a single phase, these were amalgamated together into a single entry in the dataset. On the contrary, sites for which faunal assemblages could not be allocated to a single phase (i.e. spanning multiple phases, three sites) or contained a sample size below the minimum sample size where not included for analysis (see below).

Data are restricted to taxonomic abundance by Number of Identified Specimens (NISP), one of the few forms of zooarchaeological data routinely and consistently reported across the dataset. Only counts of specimens identifiable to species or genus have been included in 
analysis; identifications to broader categories such as 'small ruminant' or 'large mammal' have been removed from comparisons. Bos sp. (indeterminate wild or domestic cattle) and Sus sp. (indeterminate wild or domestic pig) have been allocated pro rata based upon the proportions of domestic vs. wild cattle and pig in each assemblage following Orton et al. (2016). For instance, an assemblage with identified Sus remains coming $90 \%$ from domestic pig and $10 \%$ from wild boar would see Sus sp. remains allocated accordingly, with $90 \%$ of indeterminate remains included as domestic pig and the remaining $10 \%$ as wild boar. This has been done as the best means by which to account for the use of indeterminate wild or domestic Bos sp. and Sus sp. by a sub-set of faunal analysts. This form of pro-rata allocation cannot be applied with certainty to the indeterminate taxonomic category of Ovis/Capra (sheep/goat) as difficulties in distinguishing between these species in zooarchaeological identification results in the majority of identifications belonging only to this combined group. Therefore, all identified Ovis aries and Capra hircus specimens reported by analysts have been subsumed here within the larger taxonomic category Ovis/Capra, which is common across all analysts. All identified mammals larger than a hedgehog have been included in analysis; other taxonomic groups such as birds, fish or microfauna were excluded from the dataset. Where reported, numbers of shed deer antler were excluded from NISPs as these do not necessarily indicate the hunting of individuals. Following these rules, a minimum NISP cut-off of 100 taxonomically identified macromammals was applied for each phase-sample. Despite the wide range of NISP values encountered ( $\min =100$, max=5696), it is possible that larger assemblages present a much higher species diversity (or NTAXA). In order to test for this potential effect, Figure 2 plots the $\log$ (NISP) against the $\log$ (NTAXA) (following Lyman, 2015). There appears to be a weak positive correlation between NISP and NTAXA (Spearman's rho: 0.441, $p<0.05$ ), although the low $R^{2}$ value of the best-fit regression $\left(R^{2}: 0.1556, p<0.05\right)$ shows that this correlation only explains a very limited fraction of the encountered variation.

[Figure 2]

Recovery methodology varies from hand-collection to $100 \%$ wet-sieving, but is most often unspecified. The majority of faunal assemblages comes from sites which were either handcollected, or for which sieving information is not given. Hand collection (or presumed hand collection in the case of sites for which no information is given) can lead to an underrepresentation in remains of fish, birds, microfauna, small mammals and small elements from larger mammals as has been determined from experimental research (e.g. Payne 1972). This can in turn lead to the potential over-representation of larger taxa. Earlier comparisons of taxonomic abundance and diversity in Neolithic samples of different sieving regimes have shown that these need not preclude reliable taxonomic comparisons. For assemblages above the minimum sample size, overall taxonomic distributions can be compared with confidence irrespective of differences in collection, although more detailed statistical comparis ons of the representation of individual taxa cannot be made with confidence due to indeterminacies of these differences in collection (Orton et al., 2016). As hand collection may have biased recovery of small taxa, smaller elements and young animal remains, these uncertainties of collection preclude the application of more detailed analyses, such as comparisons of age profiles for domesticate taxa or micromammal-based environmental reconstructions. The recovery bias against these smaller remains increases the potential error-range of representation, creating a 'noise' of indeterminacy which 
cannot be removed but only amplified from the application of complex statistical comparisons. This is particularly the case for micromammal-based environmental reconstructions using un-sieved samples.

Data was analysed using a combination of statistical methods, all undertaken in $R(R$ Development Core Team, 2008). Ternary charts were used to represent the respective proportion of the three main categories of animal domesticates (cattle, pigs, sheep and goats; R package ggtern: Hamilton, 2017). In addition, correspondence analysis was employed to compare combined variations in the representation of all taxa between regions and phases (R packages 'ca'; Nenadić and Greenacre, 2007 and 'ggplot2'; Wickham, 2009). Correspondence analysis, a multivariate statistical tool increasingly used in zooarchaeological meta-analysis (e.g. Manning et al., 2015, Orton et al., 2016), aims at illustrating in a graphical way the relationship between sets of categorical variables. The analysis provides a series of measures, or dimensions, which explain a decreasing percentage of the total variance of the studied population. In our case, plots found on Figures 3, 5 and 8 are based on Dimension 1, which accounts for $56.65 \%$ of the variance, and Dimension 2, accounting for $22.56 \%$. Comparisons of proportions of wild and domestic taxa in assemblages was made via jitter charts, provided as SI files and created also using the $R$ package 'ggplot2'. Lastly, the distributions of taxa in each phase and region were then compared using a multivariate analysis of variance (MANOVA function in base $R$ ) to determine the potential statistical significance of identified differences in exploitation practices between site categories, regions and chronological phases.

In addition to chronological phasings, sites were further divided into six regional groupings on the basis of landscape and environment for the periods considered here (Figure 1). These groups are Dalmatia and the Trieste Karst for the eastern Adriatic and south, central, Po plain and sub-alpine Italy for the western Adriatic. These regions conform to divisions between modern biogeographical regions (European Environment Agency, 2016) as well as to variations in environmental and climatic reconstruction for the time periods considered here (see above). Southern Italy refers here to the Italian part of the Mediterranean biogeographical region, and includes Apulia, Basilicata and Calabria. Central Italy lies in the continental biogeographical region and comprises Abruzzo and the Marche. The Po plain also lies in the continental biogeographical region and covers the areas between the Apennines and the Alps. The Sub-Alpine region belongs to Sub-Alpine biogeographical region. The eastern Adriatic coast is divided into two with, on the one hand, the Dalmatian coast and its islands (Mediterranean biogeographical region) and, on the other hand, the Trieste Karst (continental biogeographical region). Summary information about these sites by region is given in Table 2 .

\section{Results}

\section{Phase 1 (c.8000 to 7500 cal. BP)}

During the initial phase of Neolithic settlement in the Adriatic both the eastern and western coasts are represented by settlements of the Impresso complex (Figure 1). Analysis of faunal material for this earliest phase shows a restricted range of animal exploitation practices, with on both coasts a focus on the management of domestic taxa and little evidence of hunting (Figure 3). Whilst all main categories of animal domesticates are observed (cattle, 
pig and sheep/goats), the representation of individual taxa varies to a limited degree. In both regions, domestic pigs are poorly represented, and the assemblage dominated by sheep and goats. The main difference corresponds to a slightly greater proportion of cattle in southern Italy than in Dalmatia.

[Figure 3]

[Figure 4]

Earliest Neolithic sites are found along the full length of the Dalmatian coast. Sheep and goat herding dominates in these assemblages (c.85\% mean Ovis/Capra across all sites) and there is little evidence in our dataset of wild animal exploitation at sites. When considering taxa excluded from our meta-analysis, especially birds, the picture is a little bit more nuanced as, for instance, bird hunting is attested on the site of Crno Vrlo (Radović 2011) While this phase is represented by a large number of cave sites, this narrow focus on sheep and goat management is also true for open-air settlements on the Ravni Kotari coastal plain and southern Istria (sites 4, 5 and 9). MANOVA comparison of both categories of settlements shows no statistical difference in taxonomic distributions $(p=0.1247)$, suggesting that this zooarchaeological pattern is one of cultural preference rather than differential functional use of cave and open sites.

As previously mentioned, whilst still dominant, there is a less narrow focus on sheep and goat herding in southern Italy (c.65\% mean Ovis/Capra) and thus a corresponding increased representation of cattle. This limited but divergent distribution of animal exploitation strategies between groups of the eastern and western Adriatic, although not statistically significant (MANOVA, $p=0.0583$ ), suggests that the Impresso culture sites overall form a circumscribed group of exploitation practices, with low levels of hunting and an overall focus on the exploitation of sheep and goats.

\section{Phase 2 (7500 to 7000 cal. BP)}

The second phase marks the generalisation of farming techniques across most of the Adriatic catchment, including central Italy and the Po plain (and beyond across the Western Mediterranean: Bocquet-Appel et al., 2009). This expansion is characterised by the location of settlements in a wider range of locations and landscapes. Domestic taxa and pottery also begin to appear in the northern reaches of the eastern Adriatic, in particular in cave sites in the northern Istrian peninsula (sites 10 and 6) and in the Trieste Karst (sites 14, 15, 16 and 17). These north-eastern Adriatic sites frequently occur in cave sites with preceding Mesolithic occupation sequences.

Within areas already settled during the first phase of the Neolithic, the patterns seen forming during the preceding phase continue. On both sides of the Adriatic low levels of hunting remain the norm with Dalmatian sites exhibiting a preference for small game such as hare (Lepus), fox (Vulpes) and hedgehog (Erinaceus). In this region, there is a continuing focus on the herding of sheep and goats (c.90\% of domesticates) and still no appreciable difference in animal exploitation between cave and open-air sites (MANOVA, $p=0.09282$ ). Conversely, the initial Neolithic settlement of the Trieste Karst shows much higher levels of hunting activity in cave sites, although there is still a relative emphasis upon sheep and goat management (c. $91 \%$ to only $42 \%$ of domesticates, with a mean of $61 \%$ ). This clear shift in 
exploitation strategies appears to be statistically significant, as indicated by the results of the MANOVA ( $p=0.02749$ ). This higher level of hunting is focused on large game, namely deer. Of the Trieste Karst sites, only Grotta degli Zingari (16) shows a notable focus on the exploitation of small game, with $67 \%$ of wild animals recorded from this site coming from small taxa compared with c. $25 \%$ at the other sites of the Trieste Karst and c. $17.5 \%$ at the high-hunting Italian sites (see below).

In southern Italy, the preference for sheep and goat management remains the norm, but within a greater range of exploitation practices (from $9 \%$ to $90 \%$ of domesticates with a mean of c.50\%). Correspondingly, a greater increase is seen in the representation of both pigs (from c. 5 to c. $63 \%$ with a mean of $19 \%$ ) and, especially cattle (from c.5\% to c. $77 \%$ with a mean of $31 \%)$. A handful of cave sites $(27,36$, and to a lesser extent 24 ) witness increased levels of hunting activity (Figure 3 ). These levels of hunting show no correspondence with variations in the percentage of sheep and goats at sites.

Settlements in central Italy, first appearing in this phase, demonstrate a similar range of exploitation practices to those of contemporaneous settlements in southern Italy. While hunting levels do not vary as greatly as seen to the south, the presence of central Italian higher-hunting outliers, both in cave (51) and open-air contexts (54) is worth noticing, especially so as they significantly differ from a statistical point of view from the main body of settlements (MANOVA, $p=0.04991$ ). A range of domesticate management practices is indicated, with variation in the focus on sheep and goats (38-73\% Ovis/Capra, mean of 56\%) and a correspondingly greater emphasis on the management of cattle (5-35\%, mean of $14 \%$ ) and especially pigs (15-46\%, mean of $29 \%$ ). These differences, however, do not present any statistical divergence from practices of sites in southern Italy (MANOVA, $p=0.4043$ ),

The first two settlements of the Po plain (67 and 80) share the overall low levels of hunting seen for sites of this phase across the western Adriatic coast ( $6 \%$ and $0.3 \%$, respectively). Although small, this sample also points to a shift away from over-reliance upon of sheep and goats $(41 \%$ and $26 \%)$ in favour of a minor focus on the management of cattle ( $48 \%$ and c. $45 \%$, respectively). This limited sample size precludes further statistical tests.

Overall, sites belonging to this phase show increased variation in animal exploitation practices, both within and between the regions considered. This variation in exploitation practices suggests a greater diversity in the utilization of landscapes (both those newly as well as previously settled) than seen in the preceding period, present across multiple regions and more commonly seen at (but not limited to) cave sites.

\section{Phase 3 (7000 to 6500 cal. BP)}

During the first half of the $7^{\text {th }}$ millennium cal. BP, settlements cover all coastal areas of the Adriatic and expand to utilize a greater diversity of landscapes, including the sub-alpine zone in Italy (Figure 1). Our dataset only includes cave sites for Dalmatia during this stage, a reflection of the global stage of knowledge (with only a single open-air site documented, unfortunately with no published fauna: Čista Mala - Velištak: Podrug 2010). Overall, one witnesses an increase in the variation of animal exploitation practices. While sites still exhibit a primary focus on domestic animal exploitation with very low levels of hunting, the dominance of sheep and goats slightly diminishes (c.80\%) in favour of cattle and pigs in 
equal proportion (c. 10\%: Figures 5 and 6 ). This process is seen both across the more arid southern coasts (sites 8 and 11) and further to the north (sites 6 and 10). By contrast, sites in the Trieste Karst show a decrease in variability, with the majority of sites now expressing a pattern of animal management identical to that of Dalmatia, with the exception of Mala Triglavca (18) where high levels of hunting continue and the representation of domesticates is more evenly distributed.

[Figure 5]

[Figure 6]

Along the western Adriatic, variation in animal exploitation practices increases in both the more arid southern and wetter northern regions. Hunting remains at low levels (c.5\%), with the exception of a single 'outlier' southern Italian cave (25; c.50\% of NISP from wild animals); the only cave site of central Italy for this phase (53) also presents a higher value of hunting $(28 \%)$, well beyond the range of open settlements (8-19\%, mean of $13 \%)$. The range of domesticate management practices in these two regions widens from the preceding two phases, a difference which is statistically significant (MANOVA, $p=0.03945$ ). While sheep and goats are still well represented on southern Italian sites (c.54\% mean), there are no longer dominant in central Italy (c.38\% mean). This decrease shows a corresponding increase in the representation of cattle (southern Italy: $35.5 \%$; central Italy: c. $30 \%$ ) and pigs (southern Italy: $10 \%)$ especially in central Italian sites (32.6\%), following trends observed during the preceding phase (Figure 5).

[Figure 7]

Zooarchaeological assemblages in the Po plain are characterised by an equal mean representation of sheep and goats (c.30\%), cattle (c.36\%) and pigs (c.34\%). This apparent pattern actually masks the variability in husbandry practices, with some settlements showing a focus on sheep and goats, some on cattle, some on pigs and some an even distribution between the domesticate taxa. Settlements of the Po plain also show highly varied levels of hunting (Figure 5). As can be seen in Figure 7, this is not restricted to upland environments but is observed across a variety of levels including both elevated and lowland settlements. In several instances, these "hunting" sites lie in the vicinity of contemporaneous settlements showing extremely low levels of wild animal exploitation (e.g. Vhó - site 84 - at $61.4 \%$ wild and Casatico di Marcaria - site 69 - at 2.2\% wild). This diversity suggests variation stemming from choice at the individual site level as to both management practices and levels of hunting intensity in contrast with sites in other regions of the Adriatic where exploitation practices vary more in line with differential use of landscapes (e.g. lowland vs. upland). This individualistic approach to exploitation practices is seen in both the overall low level of wild animal exploitation in this period for sites of the Po plain $(0.3-93 \%$ but with a mean of $27 \%$ ) as well as those initial settlements of the sub-alpine region (3-36\% with a mean of $15 \%$ ) (Figure 5). The latter show a very slight preference for the management of sheep and goats (c. $46 \%$ mean by NISP), followed by cattle (28\%) and pigs (26\%). While there is noticeable diversity of variation in domesticate management approaches seen for sites of sub-alpine Italy, this is far from the level of diversity seen in this period for the Po plain (Figure 5). 


\section{Phase 4 (6500 to 6000 cal. BP)}

During the last phase studied here, sites across the eastern Adriatic (Dalmatia and the Trieste Karst) follow the patterns of animal management seen in previous periods. Sites from Dalmatia, only represented by insular cave sites as during the previous phase, still demonstrate a pattern of low-hunting / high-sheep/goat exploitation, but with less overall variation and corresponding narrower focus on the management of sheep and goats (c.90\%). The only cave of the Trieste Karst for this phase shows animal exploitation practices (high-sheep/goat-low-hunting), in line with the records for the preceding caves in the same area, and contemporaneous ones in Dalmatia.

Along the western Adriatic there is an overall pattern of relatively low levels of hunting and a diverse array of practices regarding domesticates. Sites in the southern Italy present a higher proportion of sheep and goats (c.65\%), marking a return to levels comparable to those seen during phase one. In keeping with previously observed trends, the two cave sites from southern Italy in this phase show both high (site 36: $36 \%$ wild) and low (site $21: 1.6 \%$ wild) levels of hunting activity. Sites in central Italy show a continuation of practices seen in the preceding phase, with low overall levels of hunting (11\% wild) and a diverse but (based on mean representation) even domesticate management distribution between sheep and goats (c.5-57\% with a mean of c.35\%), cattle (c.13-51\% with a mean of c. $29 \%$ ) and pigs (c.14-70\% with a mean of c.36\%).

Settlements of the Po plain show a relatively high mean level of hunting (c.20\%), although the range of variation seen between settlements decreases when compared to phase three (Figure 5). Domesticate management preferences indicate an even distribution in mean representation of sheep and goats (c.38\%), cattle (32\%) and pigs (30\%) managed at settlements. As with hunting, the range of variation in the representation of domesticates decreases in comparison with phase three (Figure 6). As with the preceding phase, there is no demonstrable relationship between settlement location and either the levels of hunting or domesticate management preferences exhibited. Settlements of sub-alpine Italy show some diversification of practices compared with the preceding initial phase of settlement. Hunting levels, while still low overall (c.14\%), show a greater range of variation than before (see Figure 5). The minor dominance of sheep and goats previously recorded is no longer indicated, with an even representation between sheep/goat (37\%), cattle (37\%) and to a lesser extent pigs (25\%).

\section{A question of time}

In order to assess the potential role of climatic factors in shaping the variability described above, it is necessary to group sites according to their status in the local advance of farming, rather than by absolute chronological phase. By so doing one obtains two comparative groups for each region, with a 'first' (directly associated with the introduction of domesticates) and 'second' Neolithic. First Neolithic sites include the southern Italian Impresso sites, as well as the earliest settlements of the Po Plain (otherwise phase two of the previous used scheme) and those of the sub-alpine region (otherwise phase three). These are compared with sites dated to later regional phases, where Neolithic practices have had time to adapt. 
[Figure 8]

[Figure 9]

Overall, we observe a similar sequence in all regions, with a first Neolithic characterised by a relatively homogenous range of animal management practices followed by an increase in variation. These changes concern both levels of wild resource exploitation (hunting) and domesticate management practices. This variation in the second phase of the Neolithic can be noted through assemblage taxonomic compositions drawn from correspondence analysis (Figure 8), as well as of overall comparisons of the percentage representation of domesticates and domesticate proportions (Figure 9).

As already noted, a series of cave sites in the western Adriatic form 'outliers' with divergent animal exploitation practices. Within chronological phases, where enough of such examples are recorded, a significant difference in animal exploitation practices can be seen. During the initial occupation phase of central Italy, animal management practices of cave sites appear to indicate differential usage (MANOVA, $p=0.04991$ ), with a greater proportion of wild animals present than seen at open-air settlements. In the second phase of Neolithic settlement, cave sites of central and southern Italy continue to demonstrate significant differences in animal exploitation strategies (MANOVA, $p=0.01849$ ), although these differences are not systematic across all cave sites. The least variable region between these two Neolithics is, perhaps unsurprisingly, Dalmatia. However, even within the low-huntinghigh-sheep/goat trend through 2000 years of settlement, a small increase in the diversity of domesticate management can be observed during the secondary Neolithic. The focus on sheep and goats shifts from $75-99 \%$ with a mean of $93 \%$ in the first Neolithic, to $65-99 \%$ with a mean of $87 \%$. This very minor increase in variation is linked to an increase in cattle (8\%) and, to a lesser extent, pig representation (5\%) compared with initial Neolithic settlement ( $4 \%$ cattle and $2.5 \%$ pig).

Within southern Italy - closest to Dalmatia in terms of environment and climate - the increase in diversity is more noticeable, even when excluding cave sites. While hunting levels in open settlements remain constant, patterns of taxonomic preference in domesticate management show a marked increase in diversity between open settlements of the first and second Neolithic (MANOVA, $p=0.01251$ ) (Figures 8 and 9). A comparable trend is also seen for open-air settlements in central Italy (MANOVA, $p=0.02848$ ). The initial Neolithic representation in the Po plain does not include enough settlements for statistical analysis, but an increase in diversity is recorded for settlements of sub-alpine Italy (MANOVA, $p=0.04872$ ), also without any appreciable difference in wild animal exploitation. When these regions are considered together, this increase in domesticate diversity shows a significantly greater variation in practices for sites of the western than eastern Adriatic regions during the second stage of Neolithic settlement (MANOVA, $p=0.0343$ ), with a range of domesticate proportions kept at sites across Italy and no domesticate clearly dominant within a given region or phase.

By contrast, sites in the Trieste Karst show a contraction of diversity between initial and secondary phases of the Neolithic. The reduction in hunting seen between the initial and secondary Neolithic phases in this region is unique amongst the regions of the Adriatic. It is difficult to determine if the initial high diversity followed by a reduction towards a 
Dalmatian-type husbandry regime is a function of this region being known only from cave sites, or if it is indicative of a differential pattern of domesticate spread through the Trieste Karst. Irrespective of the reason behind this reversed trend in diversity through time, it is worth noting that the patterns seen during the Neolithic in the Adriatic region are common across the majority of studied regions - albeit not universal. This repetition of this pattern across multiple distinct regions, regardless of chronological, environmental or climatic categories, suggests that its interpretation lies elsewhere. As an alternative, we suggest that this initial low diversity is a (general) signature of the diffusion of early farming practices from one region to the next in the next. This reduced diversity at the earliest stages of farming is indeed seen in other aspects such as ceramic typology (Malone, 2003; Whitehouse, 2013).

\section{Discussion}

Animal exploitation strategies across the circum-Adriatic region exhibit a relatively high level of variation, from both temporal and spatial points of view. The initial Neolithic settlement of southern Italy and Dalmatia shows a restricted range of practices, dominated by the herding of sheep and goats. Such preference is in agreement with the ecology of this area, characterised by low levels of precipitation, although available palaeoenvironmental data suggest that the period presents a cooler and wetter climate. Sheep and goats remain the dominant domestic species through the diffusion of early farming across the Adriatic, indicating that each regional first Neolithic borrowed from the form of animal exploitation practiced in the neighbouring regions. This dominance of sheep and goats, however, gradually decreases in favour of more water-demanding cattle and pigs, thus mirroring the gradient in precipitation observed across the Adriatic. This pattern suggests some level of adaptation by early farming communities as they settled into new environments.

This diversity in both husbandry regimes and hunting practices continues to increase over the course of the Neolithic, parallel to the settlement of sites in a more diverse array of settings across the multiple geographic and environmental regions of the Adriatic. This being said, regional zooarchaeological patterns cannot be accounted for in terms of chronological adaptations to oscillations in climate and its environmental impacts. For instance, the changing climate of the Adriatic region during the periods considered here provides a contrast with this overall pattern of increasing diversity in animal husbandry practices. Landscape and lack of available water sources along the Dalmatian coast may have restricted husbandry choices to a focus on sheep and goats, although, if this was purely the case, one would expect that open-air settlements along the coast - the most well-watered landscapes of the region - would have a reduced dominance of these species, which is not the case. By contrast, the increased range in exploitation practices in Dalmatia occurs during the phase of greatest aridity (phase 3 ). In the same vein, southern Italy sees a gradual increase of diversity at the expense of sheep and goats, contrary to what could have been expected given the rise of aridity rises from 7000 cal. BP onwards. Likewise, be it in central Italy or in the Po valley, the observed pattern is one of diversification, rather than adaptation and specialisation on basis of the local ecological conditions. 
The same conclusion applies to variation in hunting. Along the western Adriatic coast, hunting levels remain low overall low, but with considerable diversity at both intra- and inter-regional scales, as well as between cave and open-air sites. Cave sites of in southern and central Italy, with their greater proportion of wild animals, indicate differential usages of the landscape away from open-air settlements. However, these are not geographically clustered nor do they show differentiation between sites of 'upland' and 'lowland' landscapes. This is also seen to some extent at open-air settlements of the Po plain, (otherwise a region lacking in evidence from cave sites) where a sub-set of settlements shows an emphasis on the exploitation of wild resources. All in all, it appears that animal management practices of Neolithic groups around the Adriatic were driven by cultural preferences and individual choices rather than responses to local environmental or climatic constraints.

Whilst climatic and environmental do not explain the documented variation in Adriatic Neolithic zooarchaeological assemblages, it is important to recognise that taxonomic diversity alone cannot help to define the nature of the suggested cultural preferences. Such in-depth definition of husbandry practices relies upon a wide range of data and analyses, offered by zooarchaeology and other disciplines. For instance, the development of residue analysis has confirmed the importance of dairying, from both cattle and goats, for early Neolithic communities (Spiteri et al. 2016). This key role of dairying is also reflected by ageat-death profiles, a reliable proxy for herd management, although dedicated zooarchaeological analyses are only available for a handful of sites (e.g. Gillis et al. 2016). Lastly, stable isotopes also point to differences in animal management practices. Zavodni and colleagues for instance have suggested changes in foddering regimes for pigs during the Neolithic in the eastern Adriatic (Zavodni et al. 2014; see also Tafuri et al. 2014). As new data are published, especially in the field of stable isotopes and residue analyses, this array of evidence is arguably in need for a synthesis. Our results provide, we think, a robust framework for such future work.

\section{Conclusion}

The present meta-analysis of zooarchaeological assemblages across the Adriatic catchment, an extensive yet relatively coherent area, allows for the comparative examination of patterns in husbandry regimes and hunting practices of the earliest farming communities in this part of Europe. It appears that the bulk of zooarchaeological variation cannot be explained in environmental deterministic terms. It is worth pointing out that environmental variability observed here is relatively minor, especially when compared to variation across Europe. In this sense, it is likely that environmental constraints are more noticeable in more extreme situations. Furthermore, as suggested by their limited influence upon local vegetation cover, Neolithic agricultural regimes probably operated on a limited scale to support small-sized populations (e.g. Nikulka, 2016), and thus did not necessarily required high-levels of specialisation.

Our analysis also reveals a repeated two-step trajectory, defined by lower variation in animal management during the initial stages of Neolithic settlement followed by a later increased diversity. As the latter diversity is not related to environmental variation, the 
reasons for this trajectory ought to be sought elsewhere. As suggested here, a possible explanation lies in the internal dynamics of the spread of the Neolithic, whereby the shape of each local first phase of settlement expansion is largely predetermined by the state of affairs in its area of origins (see also Guilaine, 2001). If our assumption is correct, one would thus expect this situation to be present in other regions of Europe and possibly in other facets of the archaeological record - a hypothesis which remains to be tested.

\section{Acknowledgements}

This paper is an output from the European Research Council project EUROFARM, funded under the European Union's Seventh Framework Programme (FP/20072013; ERC Grant Agreement no. 313716), led by MVL and hosted by UCL. We thank all team members and project partners, with a special thanks to those friends and colleagues who contributed unpublished data used in this analysis.

\section{References}

Albore Livadie C, Fedele F, Albarella U, de Matteis F, Esposito E and Federico R. (1988) Richerche sull Insediamento Tardo-Neolitico di Mulino Sant Antonio (Avella). Rivista di Scienze Preistoriche 41: 65-99

Allen JRM, Watts WA, McGee E and Huntley B (2002) Holocene environmental variability - the record from Lago Grande di Monticchio, Italy. Quaternary International 88: 69-80.

Amorosi A, Dinelli E, Rossi V, Vaiani SC and Sacchetto M (2008) Late Quaternary paleoenvironmental evolution of the Adriatic coastal plain and the onset of the Po River Delta. Palaeogeography, Palaeoclimatology, Palaeoecology 268: 80-90.

Barker G (1977) Further information on the Early Neolithic economy of Vhò. Preistoria Alpina 13:99-105.

Barker G (1977-1979) The animal bones, site catchment and discussion of the prehistoric economy. In: Barfield LH, Barker G, Chesterman JT, Pals JP and Voorrips A (eds) Excavation at Monte Covolo, Villanuova sul Clisi, Brescia (1972-73), Part II, Vol 13. Annali del Museo di Gavardo. Grotte Gavardo: Museo Gruppo Grotte Garvado, pp.5-88. Barker G and Clarke G (1995) Animal bones. In: Barker G (ed) A Mediterranean Valley: Landscape Archaeology and Annales History of the Bifero Valley. London: Leicester University Press, pp.111-113.

Bazzannella M (2002) La fauna della Vela di Trento: analisi preliminare. Atti della XXXIII Riunione Scientifica Preistoria e Protostoria del Trentino Alto Adige/Südtirol Trento. Florence: Instituto Italiano di Preistoria e Protostoria, pp.245-250.

Berger J-F and Guilaine J (2009) The 8200 cal. BP abrupt environmental change and the Neolithic transition: a Mediterranean perspective. Quaternary International 200: 3149.

Berto C, Bon M and Zampieri S (2012) I reperti faunistici provenienti dal sito del Neolitico recente di Botteghino (PR). In: De Grossi Mazzorin J, Saccà Dand Tozzi C (eds) Atti del 6th Convegno Nazionale di Archeozoologia. Pisa: Universita di Pisa, pp.183-186.

Biagi P and Voytek BA (1994) The Neolithisation of the Trieste Karst in northern-eastern 
Italy and its neighbouring countries. Jósa András Múzeum Évkönyve 6: 63-73.

Biagi P, Barker GWW and Cremaschi M (1983) La stazione di Casatico di marcaria (Mantova) nel quadro paleoambientale ed archeologico dell olocene antico della Val Padana centrale. Studi Archeologici 2: 45-119.

Bocquet-Appel J, Najo S, Vander Linden M. and Kozlowski JK (2009) Detection of diffusion and contact zones of early farming in Europe from the space-time distribution of 14C dates. Journal of Archaeological Science 36: 807-820.

Bökönyi S (1977-82) The Early Neolithic fauna of Rendina: a preliminary report. Origini 11: 345-350.

Bökönyi S (1983) Animal bones from test excavations of Early Neolithic ditched villages on the Tavoliere, South Italy. In: Cassano SM and Manfredi A (eds) Studi sul Neolitico del Tavoliere della Puglia. Oxford: British Archaeological Reports International Series 160, pp.237-249.

Bökönyi S (1985) A comparison of Early Neolithic domestic and wild faunas of the Balkans, Italy and south France. Cahiers ligures de préhistoire et d'archéologie 2: 181-192.

Bon M, Zampiert S and Starini E (2005) La fauna del pozzetto neolitico di Isorella (BS). In: Malera G and Visentini P (eds) Atti del 4th Convegno Nazionale di Archeozoologia. Quaderni dei Museo Archeologico del Friuli Occidentale 6:177-182.

Bon M (1996) La fauna neolitica della Grotta degli Zingari nel Carso Triestino. Atti della Società per la Praistoria e Protoistoria della Regione Friuli-Venezia Giulia, 9: 127135.

Boschin F and Riedel A (2000) The Late Mesolithic and Neolithic fauna of the Edera Cave (Aurisina, Trieste karst): a preliminary report. In: Biagi P (ed) Studi sul paleolitico, mesolitico e neolitico del bacino dell Adriatico in ricordo di Antonio M. Radmilli. Società Preistoria Protostoria Friuli-Venezia Giulia. Trieste: Quaderno, pp.73-90.

Branch NP and Marini NAF (2014) Mid-Late Holocene environmental change and human activities in the northern Apennines, Italy. Quaternary International 353: 34-51.

Caldara M, Caroli I and Simone O (2008) Holocene evolution and sea-level changes in the Battaglia basin area (eastern Gargano coast, Apulia, Italy). Quaternary International 183: 102-114.

Caldara M, Pennetta L and Simone O (2002) Holocene evolution of the Salpi Lagoon (Puglia, Italy). Journal of Coastal Research 36: 124-133.

Castelletti L and Rottoli M (2001) New data on Neolithic agriculture and environment in Northern Italy. Preistoria Alpina 33: 57-61.

Catalani P (1984) Rivarolo Mantovano: la fauna. Preistoria Alpina 20: 255-260.

Catalani P (1986) Belforte di Gazzuolo (Mantova): la fauna. In: Guerreschi G, Catalani P and Ceschin N (eds) Belforte di Gazzuolo (Mantova): una stazione con Vasi a Bocca Quadrata del Neolitico Superiore. Preistoria Alpina 22: 98-108.

Catalani P (1992) I reperti faunistici. In Guerreschi G, Catalani P, Longo G and Ionne A (eds) Una Sequenza Stratigrafica dal Neolitico Inferior all Eta imperial: I Livelli Preistorische. Bulletino di Paletnologia 83(1): 210-221.

Cazzella A, Cremaschi M, Moscoloni M and Sala B (1976) Siti neolitici in localitá Razza di Campegine (Reggio Emilia). Preistoria Alpina 12: 79-126.

Chapman J, Shiel R and Batović Š (1996) The Changing Face of Dalmatia. Leicester: Leicester University Press. 
Clark G (1992) Fauna remains: a preliminary assessment. In Malone C and Stoddart S (eds) The Neolithic site of San Marco, Gubbio (Perugia), Umbria: survey and excavation 1985-7. Papers of the British School at Rome 60: 1-69.

Colledge S, Connolly J and Shennan S (2005) The evolution of Neolithic farming from SW Asian origins to NW European limits. European Journal of Archaeology 8(2): 137156.

Combourieu-Nebout N, Peyron O, Bout-Roumazeilles V, Goring S, Dormoy I, Joannin S, Sadori L, Siani G and Magny M (2013) Holocene vegetation and climate changes in the central Mediterranean inferred from a high-resolution marine pollen record (Adriatic Sea). Climate of the Past 9: 2023-2042.

Conolly J, Manning K, Colledge S, Dobney K and Shennan S (2012) Species distribution modelling of ancient cattle from Early Neolithic sites in SW Asia and Europe. The Holocene 22(9): 997-1010.

Corridi C (1998-2000) La fauna dell'insediamento preistorico di Fontenoce di Recanti (Macerata). Origini 22: 185-194.

Cottini M, Ferrari A, Pellegatti P, Petrucci G, Rottoli M, Tasca G and Visentini P (1997) Bannia-Palazzine di Sopra (Fiume Veneto, Pordenone): scavo 1995. Atti della Società Preistoria Protostoria Friuli-Venezia Giulia 10: 119-149.

Cremonesi G (1965) Il villagio di Ripoli alla luce dei recenti scavi. Rivista di Scienze Preistoriche 20:85-155.

Cremonesi G, Meluzzi C, Pitti C and Wilkens B (1984) Grotta Azzura: scavi 1982 (nota preliminaire). Il Mesolitico sul Carso Triestino. Società per la Preistoria e Protostoria della Regione Friuli-Venezia Giulia 5: 2137.

Curci A, Michalopoulou S and Langella M (2012) Baselice: zooarchaeological study of a Neolithic village of Beneventano area. In: De Grossi Mazzorin J, Saccá D and Tozzi C (eds) Atti del 6th Convegno Nazionale di Archeozoologia. Pisa: Universita di Pisa, p p . 175177.

European Environment Agency (2016) Biogeographical regions. Available at: https://www.eea. europa.eu/data-and-maps/data/biogeographical-regions-europe-3\#tab-gisdata (accessed 17 July 2017).

De Grossi Mazzorin J (2014) L'analisi archeozoologica di alcuna siti della cultural neolitica dei vasi a bocca quadrata del Permense. Rivista di Studi Liguri 79: 87-93.

De Grossi Mazzorin J and Potenza AC (2014) Lo sfruttamento delle risorse animali nel sito neolitico di Serra Cicorra (Nardó, Lecce). Rivista di Studi Liguri 79: 101-104.

De Pompeis C (1978) Resti di un villaggio della cultural Ripoli a Città Sant'Angelo (Abruzzo). Atti della Societa Toscana di Scienze Naturali Residente in Pisa 85: 161-170.

Di Rita F, Simone O, Caldara M, Gehrels WR and Magri D (2011) Holocene environmental changes in the coastal Tavoliere Plain (Apulia, southern Italy): a multiproxy approach. Palaeogeography, Palaeoclimatology, Palaeoecology 310: 139-151.

Fernández H, Hughes S, Vigne J-D, Helmer D, Hodgins G, Miquel C, Hänni C, Luikart G and Taberlet P (2006) Divergent mtDNA lineages of goats in an Early Neolithic site, far from the initial domestication areas. Proceedings of the National Academy of Sciences 103(42): 15375-15379. 
Fiorentino G, Caldara M, De Santis V, D’Oronzo C, Mutoni IM, Simone O, Primavera M and Radina F (2013) Climate changes and human-environment interactions in the Apulia region of southeastern Italy during the Neolithic period. The Holocene 23(9): 1297-1316.

Fontana A, Mozzi B and Bondesan A (2008) Alluvial megafans in the Venetian-Friuli Plain (north-eastern Italy): evidence of sedimentary and erosive phases during Late Pleistocene and Holocene. Quaternary International 189: 71-90.

Forenbaher S, Kaiser T and Miracle PT (2013) Dating the East Adriatic Neolithic. European Journal of Archaeology 16(4): 589-609.

Forenbaher S and Perhoć Z (2015) Lithic artifacts from Nakovana (Pelješac): continuity and change from Early Neolithic until the end of prehistory. Prilozi Instituta za Arheologiju u Zagrebu 32: 5-74.

Frame SA (2008) Prehrana i gozbe u Grapčevoj Špij lji. In: Forenbaher S and Kaiser T (eds) Grapčeva Špilja: pretpovijesni stan, tor i obredno mjesto. Rezultati arheolokog istrč̌ivanj a 1996 godine. Split: Književni Krug, pp.87-120.

Gál E (2010) Faunal Analysis: Bones from animals of economic importance. In: Morter J and Robb J (eds) The Neolithic Settlemnet at Capo Alfiere. Austin: Institute of Classical Archaeology, University of Texas Press, pp.149-165.

Gillis R (2012) Osteological and Isotopic Contributions to the Study of Dairy Husbandry During the European Neolithic. PhD Thesis, Muse um National d’Histoire Naturelle Paris, France.

Gillis R, Carrère I, Saña Seguí M, Radi G and Vigne J-D (2016). Neonatal mortality, young calf slaughter and milk production during the Early Neolithic of North Western Mediterranean. International Journal of Osteorchaeology 26: 303-313.

Giove C, Ferri D, De Lucia A, Scattarella V and Pesce Delfino V (1977) La fauna del comunita neolitica di Cala Colombo. In: De Lucia A, Ferri D, Geniola A, Giove C, Maggiore M, Melone N, Pesce Delfino V, Pieri P, and Scattarella V (eds) La Comunita Neolitica di Cala Colombo Presso Torre a Mare (Bari). Bari: Società di Storia Patria per la Puglia, pp.183-251.

Giraudi C, Magny M, Zanchetta G and Drysdale RN (2011) The Holocene climactic evolution of Mediterranean Italy: a review of the continental geological data. The Holocene 21(1): 105-115.

Guilaine J (2001) La néolithisation de l'Europe. Une hpothèse arythmique. Zephyrus 53-54: 267-272.

Guilizzoni P, Lami A, Marchetto A, Jones V, Manca M and Bettinetti R (2002)

Palaeoproductivity and environmental changes during the Holocene in central Italy as recorded in two crater lakes (Albano and Nemi). Quaternary International 88: 57-68.

Hamilton N (2017) ggtern: An Extension to 'ggplot2', for the Creation of Ternary Diagrams. $R$ package version 2.2.2. https:/CRAN.R-project.org/package=ggtern.

Jahns S and van der Bogaard C (1998) New palynological and tephrostratigraphical investigations of two salt lagoons on the island of Mljet, south Dalmatia, Croatia. Vegetation History and Archaeobotany 7(4): 219-234.

Jarman M (1976) Prehistoric economic development in sub-Alpine Italy. In: Sieveking G de G, Longworth IH and Wilson KE (eds) Problems in Economic and Social Archaeology. London: Duckworth, pp.523-548. 
Langella M, Boscaino M, Coubreay S, Curci A, de Francesco AM, Senatore MR (2003) Baselice (Benevento): il sito pluristratificato neolitico do Torrente Cervaro. Rivista di Scienze Preistoriche 53:259-323.

Legge AJ and Moore AT (2011) Clutching at straw: the Early Neolithic of Croatia and the dispersal of agriculture. In: Hadjikoumis A, Robinson E and Viner S (eds) The Dynamics of Neolithisation in Europe: Studies in honour of Andrew Sherratt. Oxford: Oxbow Books, pp.177-196.

Lelli R, Allen R, Biondi G, Calattini M, Barbaro CC, Gorgoglione MA, Manfredini A, Martínez-Labarga C, Radina F, Silvestrini M, Tozzi C, Rickards O and Craig OE (2012) Examinind dietary variability of the earliest farmers of south-eastern Italy. American Journal of Physical Anthropology 149:380-390.

Lyman RL (2015). On the variable relationship between NISP and NTAXA in bird remains and animal remains. Journal of Archaeological Science 53: 291-296.

Maccari M, Boscato P and Cuda MT (2012) La fauna del sito del Neolitico recente di Chiarentana (Chianciano Terme, SI). In: De Grossi Mazzorin J, Saccá D and Tozzi C (eds) Atti del 6th Convegno Nazionale di Archeozoologia. Pisa: Universita di Pisa, pp.87-190.

Mallory JP (1984-87) Lagnano di Piede I: an Early Neolithic village in the Tavoliere. Origini 13: 193-290.

Malone C (2003) The Italian Neolithic: a synthesis of research. Journal of World Prehistory 17(3): 235-312.

Magny M, Joannin S, Galop D, Vannière B, Haas JN, Bassetti M, Bellintani P, Scandolari R and Desmet M (2012a) Holocene palaeohydrological changes in the northern Mediterranean borderlands as reflected by the lake-level record of Lake Ledro, northeastern Italy. Quaternary Research 77: 382-396.

Magny M, Peyron O, Sadori L, Ortu E, Zanchetta G, Vannière B and Tinner W (2012b) Contrasting patterns of precipitation seasonality during the Holocene in south- and northcentral Mediterranean. Journal of Quaternary Science 27(3): 290-296.

Manning K, Downey SS, Colledge S, Conolly J, Stopp B, Dobney K and Shennan S (2013). The origins and spread of stock-keeping: the role of cultural and environmental influences on early Neolithic animal exploitation in Europe. Antiquity 87: 1046-1059.

Marković Č (1985) Neolit Crne Gore. Belgrade: Philosophy Faculty.

Mazzini I, Gliozzi E, Koci R, Soulie-Märsche I, Zanchetta G, Baneschi I, Sadori L, Giardini M, Van Welden A and Bushati S (2015) Historical evolution and Middle to Late Holocene environmental changes in Lake Shkodra (Albania): New evidences from micropaleontological analysis. Palaeogeography, Palaeoclimatology, Palaeoecology 419: 47-59.

McClure SB (2013) Domesticated animals and biodiversity: early agriculture at the gates of Europe and long-term ecological consequences. Anthropocene 4: 57-68.

McClure SB (2015) The pastoral effect: niche construction, domestic animals and the spread of farming in Europe. Current Anthropology 56(6): 901-910.

McClure SB and Podrug E (2016) Villages, landscapes, and early farming in northern Dalmatia. In: Lillios KT and Chazan M (eds) Fresh Fields and Pastures New: Papers Presented in Honor of Andrew MT Moore. Leiden: Sidestone Press, pp.117-144.

McClure SB, Podrug E, Moore AMT, Culleton BJ, Kennett DJ (2014) AMS 14C chronology and ceramic sequences of early farmers in the eastern Adriatic. Radiocarbon 
56(3): 1019-1038.

Mercuri AM (2014) Genesis and evolution of the cultural landscape in central Mediterranean: the 'where, when and how' through the palynological approach. Landscape Ecology 29: 1799-1810.

Moore AT, Menušić M, Smith J and Podrug E (2007a) Project "Early Farming in Dalmatia”: Danilo Bitinj 2004-2005. Vjesnik Arheolokog Muzeja u Zagrebu 3: 1524.

Nenadić O and Greenacre M (2007) Correspondence Analysis in R, with two- and threedimensional graphics: the ca package. Journal of Statistical Software 20(3): 1-13.

Nikulka F (2016) Archäologische Demographie. Leiden: Sidestone Press.

Orton DC, Gaastra JS and Vander Linden M (2016) Between the Danube and the deep blue sea: zooarchaeological meta-analysis reveals variability in the spread and development of Neolithic farming across the Western Balkans. Open Quaternary 2(6): 1-26.

Payne S 1(972) Partial recovery and sample bias: the results of some sieving experiments. In: Higgs ES (ed) Papers in Economic Prehistory. Cambridge: Cambridge University Press, pp.49-64.

Petrucci G (1997) Resti di fauna dai livelli Neolitici e Post-Neolitici della Grotta del Mitreo nel Carso di Trieste (scavi 1967). Atti della Società Preistoria Protostoria FriuliVenezia Giulia 10:99-118.

Petrucci G (2005) La fauna. In: Visenti P (ed) Indagini nel sito neolitico di BanniaPalazzine di Sopra (Pordenone), scavi 1995-1999 e 2002-2003. Quaderni del Mueso Archeologico del Friuli Occidentale 5:146-172.

Petrucci G, Riedel A and Pessina A (2000) La fauna del canale Neolitico di Piancada (Ud). In: Malerba G, Gilli C and Giacobi G (eds) Atti del 2nd Convegno Nazionale di Archeozoologia. Forli: A.B.A.C.O., pp.193-200.

Peyron O, Magny M, Goring S, Joannin S, de Beaulieu J-L, Brugiapaglia E, Sadori L, Garfi G, Kouli K, Ioakim C and Combourieu-Nebout N (2013) Contrasting patterns of climate changes during the Holocene across the Italian peninsula reconstructed from pollen data. Climate of the Past 9: 1233-1252.

Piccarreta M, Caldara M, Capolongo D and Boenzi F (2011) Holocene geomorphic activity related to climatic change and human impact in Basilicata, Southern Italy. Geomorphology 128: 137-147.

Pilaar Birch S (2017) Neolithic subsistence at Vela Śpilja on the island of Lošinj, Croatia. In: Serjeantson D, Rowley-Conwy P and Halstead P (eds) Economic Zooarchaeology: Studies in Hunting, Herding and Early Agriculture. Oxford: Oxbow, pp. 263-268.

Pilaar Birch S and Leppard T (2016) The insular ecology and palaeoenvironmental impacts of the domestic goat (Capra hircus) in Mediterranean Neolithization. In: Ghilardi M (ed) Géoarchéologie des Îles de Méditerranée. Paris: CNRS Editions, pp.47-56

Podrug E (2010). Čista Mala - Velištak: prve tri istraživačke kampanje na nalazištu hvarske kulture / Čista Mala - Velištak: The first three excavation campaigns at a Hvar culture site. Diadora 24: 7-25.

R Development Core Team (2008) R: A language and environment for statistical computing. R Foundation for Statistical Computing, Vienna, Austria. ISBN 3-900051-07-0, URL http://www.R-project.org. 
Radović S (2011) Economija prvih stočara na istočnom Jadranu: značenje lova i stočarstva u prehrani neolitičkih ljudi (The Economy of the First Shepherds in the Eastern Adriatic: The significance of hunting and herding in the Neolithic diet). $\mathrm{PhD}$ thesis, University of Zagreb, Croatia.

Riedel A (1984a) La fauna preistorica di Cladrecis. Atti Civico Museo Storia ed Arte Trieste 14: 101-126.

Riedel A (1984b) Die Fauna der vorgeschichtlichen Fundstätte von Moletta bei Arco im Trentino. Preistoria Alpina 20: 131-138.

Riedel A (1988) The neolithic animal bones deposit of Cornuda (Treviso). Annali dell Università di Ferrara, Sezione Scienze della Terra 1(6): 71-90.

Robb J (2014) The future Neolithic: a new research agenda. In: Whittle A and Bickle P (eds) Early Farmers: The View from Archaeology and Science. Oxford: Oxford University Press, pp.21-38.

Robb J and Van Hove D (2003) Gardening, foraging and herding: Neolithic land use and social territories in Southern Italy. Antiquity 77(296): 241-254.

Roberts N, Brayshaw D, Kuzucuoğlu C, Perez R and Sadori L (2011) The mid-Holocene climatic transition in the Mediterranean: Causes and consequences. The Holocene 21(1): 3-13.

Sadori L, Jahns S and Peyron O (2011) Mid-holocene vegetation history of the central Mediterranean. The Holocene 21(1): 117-129.

Salari L, Zarattini A and Rolfo MF (2012) Nota preliminare sulla fauna del Neolitico antico di Grotta Mora Cavorso (Jenne, Lazio). In: De Grossi Mazzorin J, Saccá D and Tozzi C (eds) Atti del 6th Convegno Nazionale di Archeozoologia. Pisa: Universita di Pisa, pp.171-174.

Schwartz CA (1988) Neolithic animal husbandry of Smilčić and Nin. In: Chapman JC, Bintliff J, Gaffney V, and Slapšak B (eds) Recent Developments in Yugoslav Archaeology. British Archaeological Reports International Series 431. Archaeopress: Oxford, pp.4576.

Simonneau A, Chapron E, Vannière B, Wirth SB, Gilli A, Di Giovanni FE, Desmet M and Magny M (2013) Mass-movement and flood-induced deposits in Lake Ledro, southern Alps, Italy: implications for Holocene palaeohydrology and natural hazards. Climate of the Past 9:825-840.

Skeates R (2013) Neolithic Italy at 4004 BC: people and places. In M. Pearce and R.D. White- house (Eds.), Rethinking the Italian Neolithic. Accordia Research Papers Special Issue 13. Lon- don: Accordia Research Institute: 1-29.

Spiteri CD, Gillis RE, Roffet-Salque M, Navarro LC, Guilaine J, Manen C, Mutoni IM, Saña Segui M, Urem-Kotsou D, Whelton HL, Craig O, Vigne J-D and Evershed RP (2016) Regional asynchronicity in dairy production and processing in early farming communities of the northern Mediterranean. Proceedings of the National Academy of Sciences 113(48): 13594-13599.

Sorrentino C (1983) La fauna. In: Tiné S (ed) Passo di Corvo e la Civilta Neolitica del Tavoliere. Genova: Sagep Editrice, pp.149-157.

Sorrentino C (1984) Lo studio della fauna di Tirlecchia. In Brea, M.B. (Ed.), L’insediamento neolitico di Tirlecchia (Matera). Rivista di Scienze Preistoriche 39(1-2): 23-84. 
Spataro M (2002) The First Farming Communities of the Adriatic: Pottery Production and Circulation in the Early and Middle Neolithic. Trieste: Edizioni Svevo.

Spiteri CD, Gillis RE, Roffet-Salque M, Castells Navarro L, Guilaine J, Manen C, Muntoni IM, Segui MS, Urem-Kotsou D, Whelton HL, Craig OE, Vigne J-D and Evershed RP (2016) Regional asynchronicity in dairy production and processing in early farming communities of the northern Mediterranean. Proceeding of the National Academy of Sciences 113: 13594-13599.

Tafuri M-A, Robb J, Belcastro MG, Mariotti V, Iacumin P, Di Matteo A and O'Connell $\mathrm{T}$ (2014). Herding practices in the ditched villages of the Neolithic Tavoliere (Apulia, South-East Italy). A vicious circle? The isotopic evidence. In: Whittle A and Bickle P (eds) Early farmers. The view from archaeology and science. Oxford: Oxford University Press, pp 143-157.

Tagliacozzo A (2005) Animal exploitation in the Early Neolithic in Central-Southern Italy. Munibe (Antropologia-Arkeologia) 57: 429-439.

Tecchiati U (2015) I resti faunistici del Neolitico recente (III fase VBQ) di Maser e Monselice (Padova). In: Citton EB, Rossi S and Zanovello P (eds) Dinamiche Insediative nel Territorio dei Colli Euganei dal Paleolitico al Medioevo. Padova: Universitá degli Studi di Padova, pp.107-120.

Tecchiati U and Zanetti AL (2013) I resti faunistici dellabitato della primi fase dei vasi a bocca quadrata di Bressanone-Stufles (BZ). Atti della Accademia Roveretana degli Agiati 9(3B): 193-264.

Thomassen H (1993) La fauna. In: Martini F (ed) Grotta della Serratura a marina di Camerota culture e ambienti dei complessi holocenici. Montelupo: Garlatti e Razzai, pp.83-88.

Thun Hohenstein U, Abuhelaleh B, Petrucci G and Steffeee G (2012) La gestione delle risorse animali in un sito del Neolitico antico: risultati preliminari dello studio archeozoologico delle faune di Casalecchio di Reno (BO). In: De Grossi Mazzorin J, Saccá D and Tozzi C (eds) Atti del 6th Convegno Nazionale di Archeozoologia. Pisa: Universita di Pisa, pp.163-166.

Tunzi AM, De Leo A, D’Antonio D, Di Stefano S, Mezzazappa S and Tecchiati U (2011) Linsediamento del Neolitico tadro in località Valle Cancelli (Volturino). In: Gravina A (ed) 32 Convegno Nazionale sulla Preistoria-Protostoria-Storia della Daunia, San Severo 12-13 novembre 2011. San Severo: Archeoclub di San Severo, pp.15-44.

Turk I (1980) Začasno poročilo o najdbah favne vjami Triglavci pri Divači. Manuscript, Institute of Archaeology at ZRC-SAZU, Ljubljana, Slovenia.

Valsecchi V, Finsinger WQ, Tinner W and Amman B (2008) Testing the influence of climate, human impact and fire on the Holocene population expansion of Fagus sylvatica in the southern Prealps (Italy). The Holocene 18(4): 603-614.

Vannière B, Colombaroli D, Chapron E, Leroux A, Tinner W and Magny M (2008) Climate versus human-driven fire regimes in Mediterranean landscapes: the Holocene record of Lago dell'Accessa (Tuscany, Italy). Quaternary Science Reviews 27: 1181-1196.

Vigne J-D (2003) Les restes de vertébrés du site de Torre Sabea. In: Guilaine J and Cremonesi G (eds) Torre Sabea: un Éablissement du Néolithique Ancien en Salento. Rome: Ecole Française de Rome, pp.251-283. 
Walker MJC, Berkelhammer M, Björck S, Cwynar LC, Fisher DA, Long AJ, Lowe JJ, Newnham RM, Rasmussen SO and Weiss H (2012) Formal subdivision of the Holocene Series/Epoch: a Discussion Paper by a Working Group of INTIMATE (Integration of ice-core, marine and terrestrial records) and the Subcommission on Quaternary Stratigraphy (International Commission on Stratigraphy). Journal of Quaternary Science 27(7): 649-659. Whitehouse RD (2013) The chronology of the Neolithic ditched settlements of the Tavoliere and the Ofanto valley. In: Pearce M and Whitehouse RD (eds) Rethinking the Italian Neolithic. Accordia Research Papers Special Issue 13. London: Accordia Research Institute, pp.57-78.

Wickham H (2009) Ggplot2: Elegant Graphics for Data Analysis. New York: Springer.

Wilkens B (1985) La fauna dei livelli neolitici ed eneolitici di Attiggio. Picus 5: 204-214.

Wilkens B (1987) Il passaggio dal Mesolitico al Neolitico attraverso lo studio delle faune di alcuni siti dell'Italia centro-meridionale. $\mathrm{PhD}$ dissertation, University of Pisa, Italy.

Wilkens B (1987) La fauna del villaggio neolitico di S. Maria in Selva. Picus. Studi e ricerche sulle Marche nell'antichità 7: 169-194.

Wilkens B (1988a) La fauna di Ripa Tetta, Lucera. Nota preliminare. Taras. Rivista di Archeologia 8(1-2): 55-61.

Wilkens B (1988b) La fauna di Coppetella (Iesi, Marche). Atti della Società Toscana di Scienze Naturali, Serie A 95::363-378.

Wilkens B (1988c) I resti faunistici di Piano Donatelli (neolitico). Le Marche. Archeologia, Storia, Territorio 1: 127-136.

Wilkens B (1989a) Berbentina di Sassoferrato: i resti faunistici. Atti della Società Toscana di Scienze Naturali, Serie A 96: 257-267.

Wilkens B (1989b) La fauna neolitica di Monte Tinello (Marche). Atti della Società Toscana di Scienze Naturali, Serie A 96: 269-289.

Wilkens B (1996) Lago del Rendina, sito 3. In: Tiné V (ed) Forme e Tempi della Neolitizzazione in Italia Meridionale e in Sicilia, Atti del Seminario Internazionale, Rossano, 29 aprile-2 maggio 1994. Rubbettino: Soveria Mannelli, pp.513-519.

Wilkens B (2002) Gli animali del Neolitico Antico nella Puglia centrale, In: Radina F (ed) Paesaggi, Uomini e Tradizioni di 8000 anni fa: La Preistoria della Puglia. Bari: M. Adda Editore, pp.215-220.

Wilkens B (2003) La fauna. In: Tozzí C and Zamagni B (eds) Gli Scavi nel Villaggio Neolitico di Catignano (1971-1980). Florence: Italian Institute of Pre- and Protohistory, pp.219-238.

Wunsama S, Schmidt R and Müller J (1999) Holocene lake development of two Dalmatian lagoons (Malo and Veliko Jezero, Isle of Mljet) in respect to changes in Adriatic sea level and climate. Palaeogeography, Palaeoclimatology, Palaeoecology 146: 251-281.

Zavodny E, McClure SB, Culleton BJ, Podrug E, and Kennett DJ (2014). Neolithic animal management practices and stable isotope studies in the Adriatic. Environmental Archaeology 19: 184-195.

\section{Figure Captions}


Figure 1: Geographic distribution and locations of sites used in this study. Sites have been divided into chronological phases 1-4 as follows: [A] Phase 1 (8000-7500 cal. BP); [B] Phase 2 (7500-7000 cal. BP); [C] Phase 3 (7000-6500 cal. BP); and [D] Phase 4 (6500-6000 cal. BP).

Figure 2: Graphical representation of the relationship between sample size (NISP) and taxonomic diversity (NTAXA) for the site samples studied.

Figure 3: Taxonomic representation of sites by region from phases 1 and 2 (c.8000 to $7000 \mathrm{cal}$. BP) expressed via correspondence analysis.

Figure 4: Ternary diagrams for domesticate proportions by region for phases 1 and 2 (8000 to 7000 cal. $\mathrm{BP})$.

Figure 5: Taxonomic representation of sites by region from phases 3 and 4 (c.7000 to 6000 cal. BP) expressed via correspondence analysis.

Figure 6: Ternary diagrams for domesticate proportions by region for phases 3 and 4 (7000-6000 cal. $\mathrm{BP})$.

Figure 7: Intensity of hunting for sites of the Po Plain (all phases).

Figure 8: Taxonomic representation of sites by region for initial and secondary phases of Neolithic settlement expressed via correspondence analysis.

Figure 9: Ternary diagrams for domesticate proportions in primary and secondary Neolithics for each region.

Figure SI1: Proportion of wild taxa in assemblages by region for samples of Phase 1 (8000-7500 cal. BP).

Figure SI2: Proportion of wild taxa in assemblages by region for samples of Phase 2 (7500-7000 cal. BP).

Figure SI3: Proportion of wild taxa in assemblages by region for samples of Phase 3 (7000-6500 cal. $\mathrm{BP})$.

Figure SI4: Proportion of wild taxa in assemblages by region for samples of Phase 4 (6500-6000 cal. BP).

Figure SI5: Proportion of wild taxa in assemblages by region for samples of 'first' Neolithic sites.

Figure SI6: Proportion of wild taxa in assemblages by region for samples of 'second' Neolithic sites. 